\title{
Effects of Lentinan alone and in combination with fluoropyrimidine anticancer agent on growth of human oral squamous cell carcinoma in vitro and in vivo
}

\author{
KOJI HARADA, YASUTAKA ITASHIKI, TAKANORI TAKENAWA and YOSHIYA UEYAMA
}

\author{
Department of Oral and Maxillofacial Surgery, Yamaguchi University Graduate \\ School of Medicine, 1-1-1 Minamikogushi, Ube 755-8505, Japan
}

Received March 29, 2010; Accepted May 14, 2010

DOI: 10.3892/ijo_00000711

\begin{abstract}
Chemotherapy has shown little antitumor activity against advanced oral squamous cell carcinoma (OSCC) patients. Therefore, there is an urgent need to develop more effective therapeutic methods for patients with advanced OSCC. Lentinan, B-(1 $\rightarrow 3)$-D-glucan, an extract from the edible mushroom, Lentinus edodes, has been reported to show direct antitumor effects and various immunomodulatory effects. S-1 is an oral antineoplastic agent that can induce apoptosis in various types of cancer cells, including OSCC. Hence, combined treatment of cancer cells with Lentinan and S-1 might exert dramatic antitumor effects on OSCC cells. In this study, the response of human OSCC cells to Lentinan alone and in combination with $\mathrm{S}-1$ was examined using nude mouse xenograft models. S-1 (6.9 mg/kg/day, 7 times/week $)$ was administered orally and Lentinan $(0.1 \mathrm{mg} / \mathrm{kg} / \mathrm{day}, 2$ times/ week) was injected into peritumoral tissue for three weeks. Apoptotic cells were detected by a TUNEL method. The gene expression level of thymidylate synthase (TS), dihydropyrimidine dehydrogenase (DPD) and orotate phosphoribosyl transferase (OPRT) was determined using microdissection and RT-PCR, and their protein levels were determined using ELISA. Combined therapy of Lentinan and S-1 markedly exerted antitumor effects on human OSCC xenografts and significantly induced apoptotic cells in tumors treated with Lentinan plus S-1. Microdissection and RT-PCR revealed that the expression of TS and DPD mRNA was downregulated and that expression of OPRT mRNA was upregulated in tumors administered the combined treatment. Moreover, ELISA indicated that the protein levels of TS and DPD were down-regulated, and that OPRT was up-regulated
\end{abstract}

Correspondence to: Dr Koji Harada, Department of Oral and Maxillofacial Surgery, Yamaguchi University Graduate School of Medicine, 1-1-1 Minamikogushi, Ube 755-8505, Japan

E-mail: harako@yamaguchi-u.ac.jp

Key words: Lentinan, 5-fluorouracil, S-1, oral squamous cell carcinoma, apoptosis in tumors treated with the combined therapy. During the experimental period, no loss of body weight was observed in mice treated with the combined therapy. These findings demonstrate that the combination of Lentinan and S-1 is effective against OSCC and has the potential of being a new therapeutic tool for future treatment of these tumors.

\section{Introduction}

Cancers of the oral cavity accounted for 274,000 cases in 2002 , with almost two-thirds of them in men. Also, they are the 11 th most common cancer in males and 13th in females in developed countries, and 6th in males and 10th in females in developing countries (1). Oral squamous cell carcinoma (OSCC) occupies the majority of oral cancers. Three major modalities (surgery, radiation and chemotherapy) are widely applied as conventional treatment strategies to OSCC. However, extensive operation or systemic chemotherapy is not often suitable for OSCC patients of advanced age or with complications. Therefore, new therapeutic agents are required to improve the efficiency of the conventional chemotherapies for OSCC.

$\mathrm{S}-1$ is a novel oral anticancer drug that is a combination of tegafur (FT), 5-chloro-2,4-dihydroxypyridine (CDHP) and oteracil potassium (Oxo) in a 1:0.4:1 molar concentration ratio (2). FT is a pro-drug of 5-fluorouracil (5-FU). CDHP is a competitive inhibitor of dihydropyrimidine dehydrogenase (DPD), which is involved in the degradation of 5-FU, and acts to maintain efficacious concentrations of 5-FU in plasma and tumor tissues (3). Oxo, a competitive inhibitor of orotate phosphoribosyltransferase (OPRT), inhibits the phosphorylation of 5-FU in the gastrointestinal tract, reducing the serious gastrointestinal toxicity associated with 5-FU (4). S-1 therapy in athymic nude rats was associated with the retention of a higher and more prolonged concentration of 5-FU in plasma and tumor tissues when compared with tegafur/uracil (UFT) (5). The antitumor effect of S-1 has been already demonstrated in a variety of solid tumors: the response rates for advanced gastric cancer (6), colorectal cancer (7), non-small cell lung cancer (8), head and neck cancer (9) and oral cancer (10) in the phase II studies conducted in Japan were 44-49, $35,22,29$ and $41.5 \%$, respectively. The efficacy of S-1 for the treatment of gastrointestinal cancer has also been reported in European patients: the response rates for advanced gastric 
cancer (11) and colorectal cancer (12) were 32 and 24\%, respectively. Despite $\mathrm{S}-1$ being effective against various cancers, systemic chemotherapy should be considered if S-1 single-agent therapy is inadequate against advanced or recurrent tumors.

Recently, a wide variety of factors involved in the prediction of chemotherapy with 5-FU against gastrointestinal carcinoma including OSCC was identified (13). The degree of thymidylate synthase (TS), DPD and OPRT protein expression is thought to be one of the most reliable factors. Many studies have reported that various carcinomas with higher expression of TS, DPD and lower expression of OPRT may resist 5-FUbased chemotherapy (14-16).

Lentinan (LNT), $\beta$-( $1 \rightarrow 3)$-D-glucan, an extract from the edible mushroom, Lentinus edodes, has been reported to show direct antitumor effects $(5,17)$ and various immunomodulatory effects; for example, LNT is able to activate CTLs $(18,19)$, LAK cells, NK cells and macrophages (20), and to improve Th1/Th2 cytokine balance (21). LNT has been used to treat cancer patients as a biological response modifier (BRM) with cancer chemotherapy, and has been reported to improve the quality of life of the patients and prolong their survival periods (22). Recently, the B-glucan receptor was identified and characterized (4,23), and B-glucan has been reported to affect phagocytosis of monocytes and macrophages. Thus, LNT may exert various actions on cancer therapy. However, LNT in combination of tegafur is only approved for enhancing a survival benefit against unresectable or recurrence gastric cancer in Japan. Hence, in this study, we investigated whether the combination of LNT and S-1 can augment S-1-induced apoptosis in OSCC xenografts or not. In addition, possible underlying mechanisms involved in the enhancement of apoptosis-inducing activity of S-1 by LNT were examined.

\section{Materials and methods}

Cell lines and cell culture. KB cells were obtained from Human Science Research Resources Bank (Osaka, Japan). HSC3 cells were obtained from Cell Bank (Tsukuba, Japan). $\mathrm{KB}$ and HSC3 cells were cultured in Dulbecco's modified Eagle's medium (DMEM) supplemented with $10 \%$ fetal bovine serum (FBS), $100 \mu \mathrm{g} / \mathrm{ml}$ streptomycin and 100 units/ $\mathrm{ml}$ penicillin in a humidified atmosphere containing $5 \%$ $\mathrm{CO}_{2}$.

MTT assay. Cells were seeded in 96-well plates (Franklin lakes, Becton-Dickinson, NJ, USA) at $5 \times 10^{3}$ cells per well in DMEM containing $10 \%$ FBS. After $24 \mathrm{~h}$, the culture medium in each well was replaced with new medium containing appropriate agents. Following various treatments, the number of cells was quantitated by an assay in which MTT [3-(4,5dimethylthiazol-2-yl)-2,5-diphenyltetrazolium bromide (Sigma-Aldrich, St. Louis, MO, USA)] was used (24).

Cell cycle analysis. After various treatments of cells, the attached and floating cells were collected in conical tubes (Becton-Dickinson). Then, the cells were fixed with $70 \%$ ethanol and washed with phosphate-buffered saline (PBS).
After treatment with $100 \mu \mathrm{g} / \mathrm{ml}$ of RNaseA (Sigma-Aldrich), the cells were stained with $40 \mu \mathrm{g} / \mathrm{ml}$ propidium iodine (Molecular Probes, Eugene, OR, USA), and the cell cycle was analysed by a digital flow cytometry system EPICS (Coulter, Miami, FL, USA).

Western blot analysis. Cytosolic protein was isolated from various treated cells. The soluble protein was separated on $10 \%$ SDS-PAGE by electrophoresis and electrophoretically transferred onto PVDF membrane, and the membrane was incubated with a 1:500 dilution of the rabbit polyclonal antibody against TS, DPD and OPRT (obtained from Taiho Pharmaceutical Co., Ltd., Tokyo, Japan), and an chromogenic immunodetection system, Western Breeze (Invitrogen, Carlsbad, CA, USA). Also, anti- $\alpha$-tubulin monoclonal antibody (Zymed Laboratories, San Francisco, CA, USA) was used for normalization of Western blot analysis.

Nude mice and tumor inoculations. Female athymic nude mice with CAnN.Cg-Foxnlnu/CrlCrlj genetic background (CLEA Japan, Inc., Tokyo, Japan) were purchased at 4 weeks of age and kept under sterile conditions in a pathogen-free environment. The mice were provided with sterile water and food ad libitum and all manipulations were carried out aseptically inside a laminar flow hood. KB cells were used as a xenograft model in the nude mice. Briefly, tumor cells $\left(1 \times 10^{6}\right)$ were suspended in $0.1 \mathrm{ml}$ of serum-free medium and injected into the subcutaneous tissue of 5-week-old nude mice (average weight $20.0 \mathrm{~g}$ ) using a 27 -gauge needle. Tumors were allowed to grow for 10 days before treatment. The mice were then divided into 4 groups, each of 5 mice with similar mean tumor volumes $\left(100-150 \mathrm{~mm}^{3}\right)$. Yamaguchi University committee on use and care of animals approved all experiments.

Reagents and treatment protocol. LNT was obtained from Ajinomoto Co., Ltd. (Tokyo, Japan). The reagent $(0.1 \mathrm{mg} / \mathrm{kg} /$ day) was injected into peritumoral tissue for 3 weeks (2 times/ week). S-1 was obtained from Taiho Pharmaceutical Co., Ltd. The drug was suspended in auto-claved $0.5 \%$ sodium hydroxypropylmethylcellulose (HPMC; Daiichi Seiyakukogyo, Kyoto, Japan) in sterile conditions, at $1.0 \mathrm{mg} / \mathrm{ml}$, and subsequently homogenized by stirring. The suspension was given to mice via a gastric tube in a volume of $0.1 \mathrm{ml} / 10 \mathrm{~g}$ body weight for 3 weeks ( 7 times/week). Mice in control groups were administered orally with an equal volume of $0.5 \%$ HPMC for 3 weeks (7 times/week), and that received saline $(200 \mu 1)$ intraperitoneally. Mice in S-1 groups were administered orally with S-1 $(6.9 \mathrm{mg} / \mathrm{kg}$ ) for 3 weeks (7 times/ week). Mice in LNT group were injected LNT $(0.1 \mathrm{mg} / \mathrm{kg})$ into peritumoral tissue for 3 weeks (2 times/week). Mice in S-1 plus LNT groups were administered orally with S-1 $(6.9 \mathrm{mg} / \mathrm{kg})$ for 3 weeks (7 times/week), and that injected LNT $(0.1 \mathrm{mg} / \mathrm{kg})$ into peritumoral tissue for 3 weeks (2 times/ week). The size of these tumors was measured every two days and the relative tumor volumes were calculated. At 21 days, mice were sacrificed by cervical dislocation and the tumors were dissected out, fixed in neutral-buffered formalin and embedded in paraffin, or frozen in liquid nitrogen for further study. 
TUNEL (terminal deoxynucleotidyl transferase (Tdt)mediated nick end labeling) assay. To detect apoptotic cells, the ApopTag Plus peroxidase in situ Apoptosis Detection kit (Intergen Co., Purchase, NY, USA) was used. Paraffin sections (5- $\mu$ m-thick) of tumor were deparaffinized in xylene and rehydrated in decreasing concentrations of ethanol. Tissue sections were incubated in $20 \mu \mathrm{g} / \mathrm{ml}$ proteinase $\mathrm{K}$ (Dako Corp., Carpinteria, CA, USA) for $15 \mathrm{~min}$. After sections were rinsed in distilled water, endogenous peroxidase was blocked by incubating the slides in $3 \%$ hydrogen peroxide in PBS (0.05 M phosphate buffer containing $0.145 \mathrm{M}$ sodium chloride, $\mathrm{pH}$ 7.4) for $5 \mathrm{~min}$. After being washed with PBS, the sections were incubated with equilibration buffer and then TdT enzyme in a humidified chamber at $37^{\circ} \mathrm{C}$ for $60 \mathrm{~min}$. They were subsequently put into prewarmed working strength stop wash buffer for $10 \mathrm{~min}$. After being rinsed in PBS, the sections were incubated with antidigoxigenin-peroxidase conjugate for $30 \mathrm{~min}$. Peroxidase activity in each section was demonstrated by the application of diaminobenzidine (Peroxidase Substrate kit; Vector Laboratories). Hematoxylin was used as a counterstain. At least 1000 cells were counted under a microscope in several random fields of each section. The number of apoptotic cells was divided by the total number of cells counted and the result was expressed as a percentage.

Microdissection. A representative formalin-fixed, paraffinembedded (FFPE) tumor specimen, containing a central section of the cancer, was selected from each of the lesions by a pathologist after examination of the hematoxylin and eosinstained slides. Sections of $10 \mu \mathrm{m}$ were stained with nuclear fast red to enable visualization of histology for laser-captured microdissection (PALM Microlaser Technologies, Munich, Germany), which was performed to ensure both malignant cells and normal stromal cells were studied.

RNA extraction and cDNA synthesis from paraffin-embedded tissues. RNA was extracted according to the method of Chomczynski and Sacchi with minor modifications (25). Briefly, $600 \mu 1$ of xylene were added to each sample tube containing micro-dissected sections. After centrifugation for $7 \mathrm{~min}$ at $20800 \mathrm{x} \mathrm{g}$, the supernatant was discarded, and the washing step was repeated 3 times. The deparaffinized materials were rehydrated in xylene:ethanol:water at the following ratios (95:95:5, 95:90:10, 95:80:20, 95:75:25 and 95:70:30). After each step, the rehydration medium was removed after centrifugation for $7 \mathrm{~min}$ at $20800 \mathrm{x} \mathrm{g}$. After discarding the last supernatant, the pelleted sections were redissolved in $70 \%$ ethanol. Subsequently, $400 \mu 1$ of buffer (4 M guanidine isothiocyanate solution including $0.5 \%$ sarcosine and $8 \mu 11 \mathrm{M}$ DTT) were added to the dried tissue and homogenized mechanically. For RNA denaturation, homogenates were heated at $95^{\circ} \mathrm{C}$ for $30 \mathrm{~min}$. RNA was extracted from homogenates by the addition of $50 \mu 1$ of $2 \mathrm{M}$ sodium acetate ( $\mathrm{pH} 4.0), 500 \mu 1$ of water-saturated phenol and $100 \mu \mathrm{l}$ of a chloroform-isoamyl mixture (49:1). RNA was recovered from the aqueous phase by isopropanol precipitation and transferred to a fresh tube and precipitated with $10 \mu \mathrm{l}$ glycogen and $400 \mu \mathrm{l}$ isopropanol for $30 \mathrm{~min}$ at $-20^{\circ} \mathrm{C}$. After centrifuging for $7 \mathrm{~min}$ at $20800 \mathrm{~g}$, the pellet was washed with $500 \mu 175 \%$ ethanol. After drying, the pellet was dissolved in $50 \mu 15 \mathrm{mM}$ Tris- $\mathrm{HCl}(\mathrm{pH} 8.0)$. Reverse transcription was carried out at $39^{\circ} \mathrm{C}$ for 45 min using 400 units of M-MLV reverse transcriptase, $1 \mathrm{X}$ first-strand buffer, $0.04 \mu \mathrm{g} / \mu \mathrm{l}$ random hexamers, $10 \mathrm{mM}$ DTT and $1 \mathrm{mM}$ deoxynucleoside triphosphate (all reagents were purchased from Promega Corp., Madison, WI, USA).

PCR quantification of $m R N A$ expression. Target cDNA sequences were amplified by quantitative PCR using a fluorescence-based real-time detection method (ABI PRISM 7900 Sequence Detection System, TaqMan; Applied Biosystems, Foster City, CA, USA). PCR was carried out for each gene of interest with $B$-actin was used as an internal reference gene. The $25 \mu \mathrm{l}$ PCR reaction mixture contained $600 \mathrm{nmol} / \mathrm{l}$ of each primer, $200 \mathrm{nmol} / \mathrm{l}$ each of dATP, dCTP and dGTP, $400 \mathrm{~mol} / 1 \mathrm{dUTP}, 5.5 \mathrm{mmol} / 1 \mathrm{MgCl}_{2}$ and $1 \mathrm{X}$ TaqMan buffer. A containing a reference dye (all reagents were purchased from Applied Biosystems). The primers and probe sequences used were as follows: TS primers: GCCT CGGTGTGCCTTTCA and CCCGTGATGTGCGCAAT, probe 6 FAM (carboxyfluorescein)-5-TCGCCAGCTACGCC CTGCTCA-3TAMRA ( $N, N, N, N$-tetra methyl-6-carboxyrhodamine); DPD primers: AGGACGCAAGGAGGGTTTG and GTCCGCCGAGTCCTTACTGA, probe 6 FAM-5CAGTGCCTACAGTCTCGAGTCTGCCAGTG-3TAMRA; OPRT primers: TAGTGTTTTGGAAACTGTTGAGGTT and CTTGCCTCCCTGCTCTCTGT, probe 6FAM-TGGCA TCAGTGACCTTCAAGCCCTCCT; ß-actin primers: TGAG CGCGGCTACAGCTT and TCCTTAATGTCACGCAC GATTT, probe 6FAM-5-ACCACCACGGCCGAGCGG3TAMRA. The PCR conditions were $50^{\circ} \mathrm{C}$ for $10 \mathrm{sec}$ and $95^{\circ} \mathrm{C}$ for $10 \mathrm{~min}$, followed by 42 cycles at $95^{\circ} \mathrm{C}$ for $15 \mathrm{sec}$ and $60^{\circ} \mathrm{C}$ for $1 \mathrm{~min}$. The relative gene expressions of TS, DPD and OPRT were determined based on the threshold cycles of each gene in relation to the threshold cycle of the corresponding internal standard $\beta$-actin. The use of $\beta$-actin as a reference gene avoids the need for RNA concentration measurement. The $B$-actin real-time PCR analysis also estimated the amount of extracted mRNA. The rise of the $B-$ actin signal after cycle 37 using the described conditions indicated an insufficient amount of mRNA present for the subsequent TS, DPD and OPRT quatification. When measuring gene expressions in paraffin-embedded tissues, the median value of the threshold cycle of $B$-actin was 26 cycles, ranging from 23 to 28 , in malignant tissues.

Enzyme-linked immunosorbent assay for TS, DPD and $O P R T$. The TS, DPD and OPRT expression levels in culture cells and nude mouse tumors were each measured by enzymelinked immunosorbent assay (ELISA) according to the methods of Mori et al (26), Kurebayashi et al (27) and Tsuji et al (28), respectively.

Statistical analysis. The statistical significance was set at $\mathrm{P}<0.05$. Statistical analyses were performed using the StatView software (version 5.0J, SAS Institute Inc., Cary, NC, USA).

\section{Results}

Effect of LNT alone and in combination with 5-FU on in vitro cell growth. We tested the effect of LNT at four concentrations on in vitro cell growth of KB and HSC3 cells. A low 


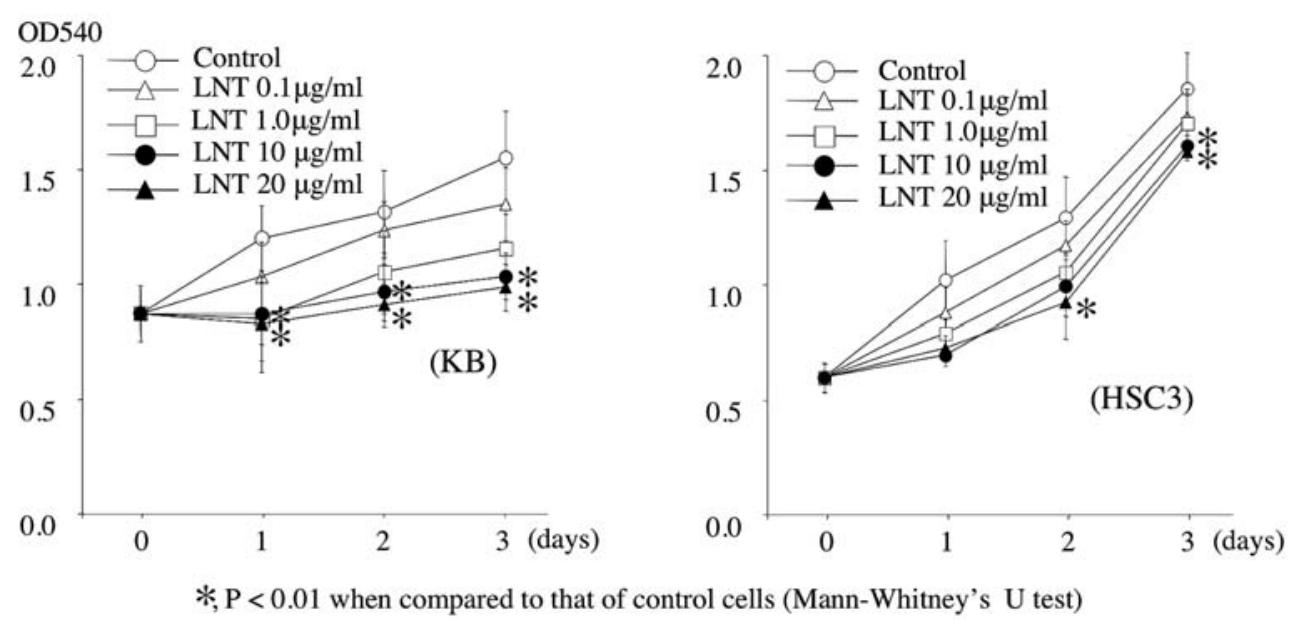

Figure 1. Growth inhibitory effect of LNT on KB and HSC3 cells. Cells $\left(5 \times 10^{3}\right.$ cells/well) were seeded into 96-well plates and exposed to LNT at the indicated concentration in 10\% FBS-supplemented medium. At $0,1,2$ and 3 days, cells were counted using a microplate reader. LNT (10-20 $\mu \mathrm{g} / \mathrm{ml})$ significantly suppressed the growth of KB and HSC3 cells when compared with that of control (LNT $0 \mu \mathrm{g} / \mathrm{ml}$ ). Each data point represents the mean of sixindependent determinations.

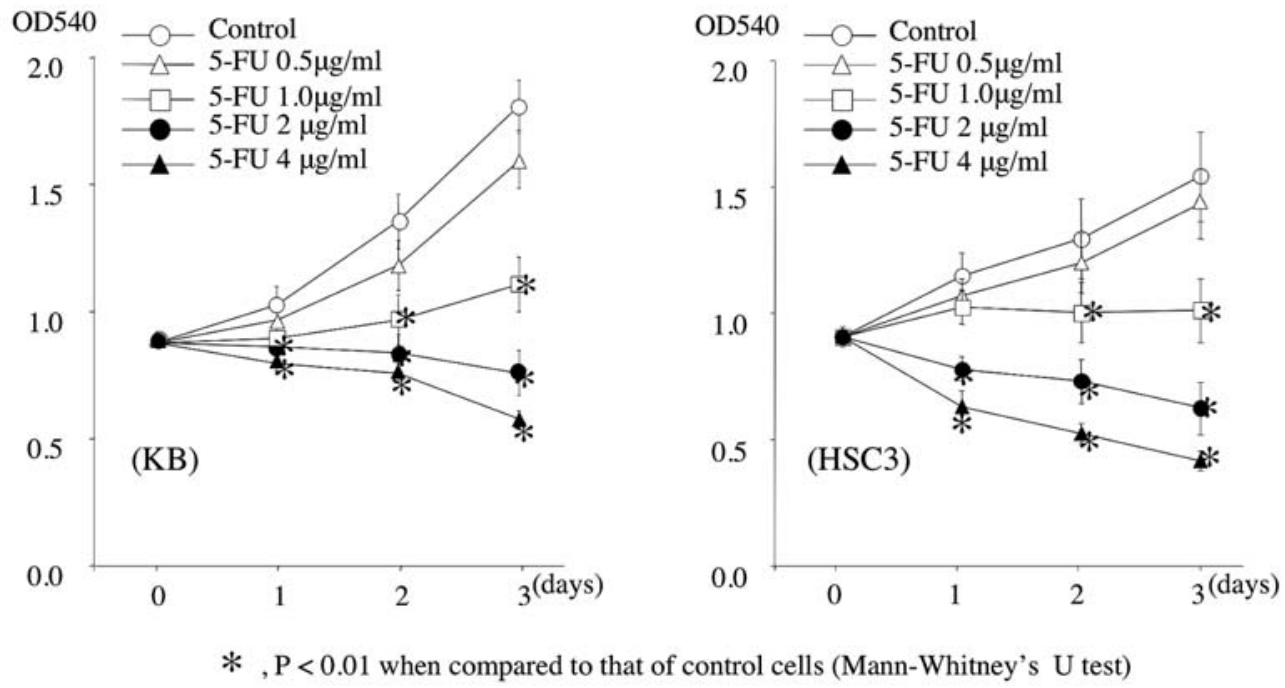

Figure 2. Growth inhibitory effect of 5-FU on KB and HSC3 cells. Cells $\left(5 \times 10^{3}\right.$ cells/well) were seeded into 96-well plates and exposed to 5-FU at the indicated concentration in 10\% FBS-supplemented medium. At $0,1,2$ and 3 days, cells were counted using a microplate reader. 5-FU (1.0-4 $\mu \mathrm{g} / \mathrm{ml})$ significantly suppressed the growth of KB and $\mathrm{HSC} 3$ when compared with that of control $(5-\mathrm{FU} 0 \mu \mathrm{g} / \mathrm{ml})$. Each data point represents the mean of sixindependent determinations.

concentration of LNT $(0.1-1.0 \mu \mathrm{g} / \mathrm{ml})$ did not suppress the cell growth of $\mathrm{KB}$ and HSC3 cells. However, high concentrations of LNT $(10-20 \mu \mathrm{g} / \mathrm{ml})$ significantly suppressed the growth of $\mathrm{KB}$ and $\mathrm{HSC} 3$ cells when compared with that of control (LNT $0 \mu \mathrm{g} / \mathrm{ml}$ ) (Fig. 1). Moreover, a low concentration of $5-\mathrm{FU}(0.5 \mu \mathrm{g} / \mathrm{ml})$ did not suppress the cell growth of KB and HSC3 cells, but high concentrations of 5-FU (1.0$4 \mu \mathrm{g} / \mathrm{ml}$ ) significantly suppressed the growth of KB and HSC3 when compared with that of control (5-FU $0 \mu \mathrm{g} / \mathrm{ml}$ ) (Fig. 2).

As LNT preferentially suppressed the growth of KB cells when compared with HSC3 cells, we decided to use KB cells for further investigation.

Combined treatment of LNT $(10 \mu \mathrm{g} / \mathrm{ml})$ and 5-FU $(1 \mu \mathrm{g} /$ $\mathrm{ml}$ ) significantly suppressed the growth of $\mathrm{KB}$ cells when compared with that of single treatment of 5-FU $(1 \mu \mathrm{g} / \mathrm{ml})$ or
LNT $(10 \mu \mathrm{g} / \mathrm{ml})$. In addition, treatment of LNT $(10 \mu \mathrm{g} / \mathrm{ml})$ for $24 \mathrm{~h}$ before $5-\mathrm{FU}(1 \mu \mathrm{g} / \mathrm{ml})$ for $24 \mathrm{~h}$ was more effective than concurrent treatment [LNT $(10 \mu \mathrm{g} / \mathrm{ml})+5$-FU $(1 \mu \mathrm{g} / \mathrm{ml})$ ] for $48 \mathrm{~h}$. However, there was no significance between the treatment of LNT $(10 \mu \mathrm{g} / \mathrm{ml})$ for $24 \mathrm{~h}$ before 5-FU $(1 \mu \mathrm{g} / \mathrm{ml})$ for $24 \mathrm{~h}$ and the treatment of 5-FU $(1 \mu \mathrm{g} / \mathrm{ml})$ for $24 \mathrm{~h}$ before the treatment of LNT $(10 \mu \mathrm{g} / \mathrm{ml})$ for $24 \mathrm{~h}$. We did not detect significance between the concurrent treatment [LNT (10 $\mu \mathrm{g} / \mathrm{ml})+5-\mathrm{FU}(1 \mu \mathrm{g} / \mathrm{ml})]$ for $48 \mathrm{~h}$ or the treatment of $5-\mathrm{FU}$ $(1 \mu \mathrm{g} / \mathrm{ml})$ for $24 \mathrm{~h}$ before the treatment of LNT $(10 \mu \mathrm{g} / \mathrm{ml})$ for $24 \mathrm{~h}$ (Fig. 3). Briefly, it was thought that the pretreatment of LNT might be more effective than concurrent treatment of LNT and 5-FU. We tested for a suitable pre-treatment time for LNT. Treatment of LNT $(10 \mu \mathrm{g} / \mathrm{ml})$ for $6 \mathrm{~h}$ before 5-FU $(1 \mu \mathrm{g} / \mathrm{ml})$ for $42 \mathrm{~h}$ was more effective than treatment of LNT 


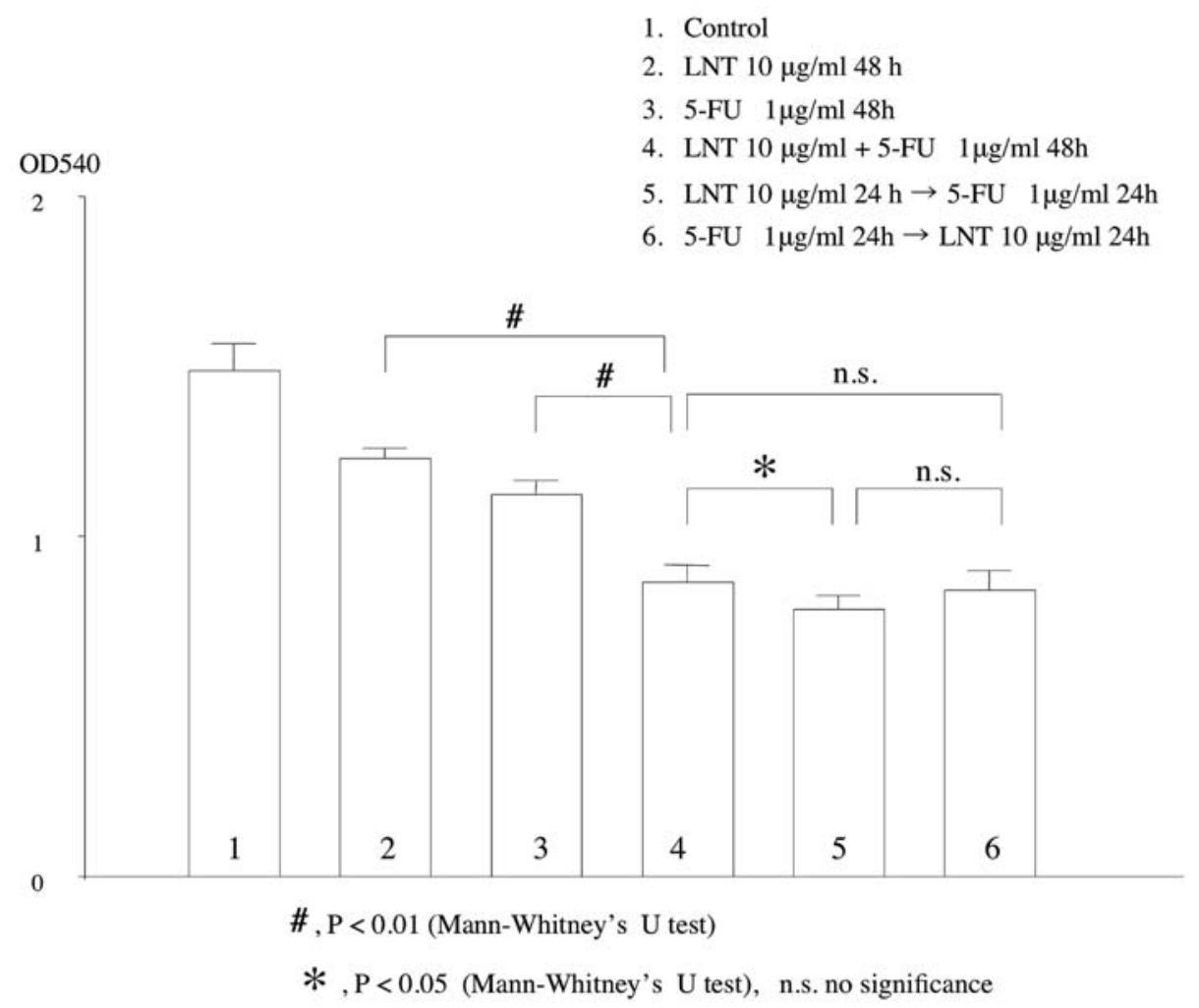

Figure 3. Growth inhibitory effect of LNT in combination with 5-FU on KB cells. Cells (5x10 $10^{3}$ cells/well) were seeded into 96-well plates and exposed to LNT and/or 5-FU at the indicated concentration in 10\% FBS-supplemented medium. At different time intervals, cells were counted using a microplate reader. Pretreatment of LNT $(10 \mu \mathrm{g} / \mathrm{ml})$ before 5-FU $(1 \mu \mathrm{g} / \mathrm{ml})$ was more effective than concurrent treatment. Each data point represents the mean of six-independent determinations.

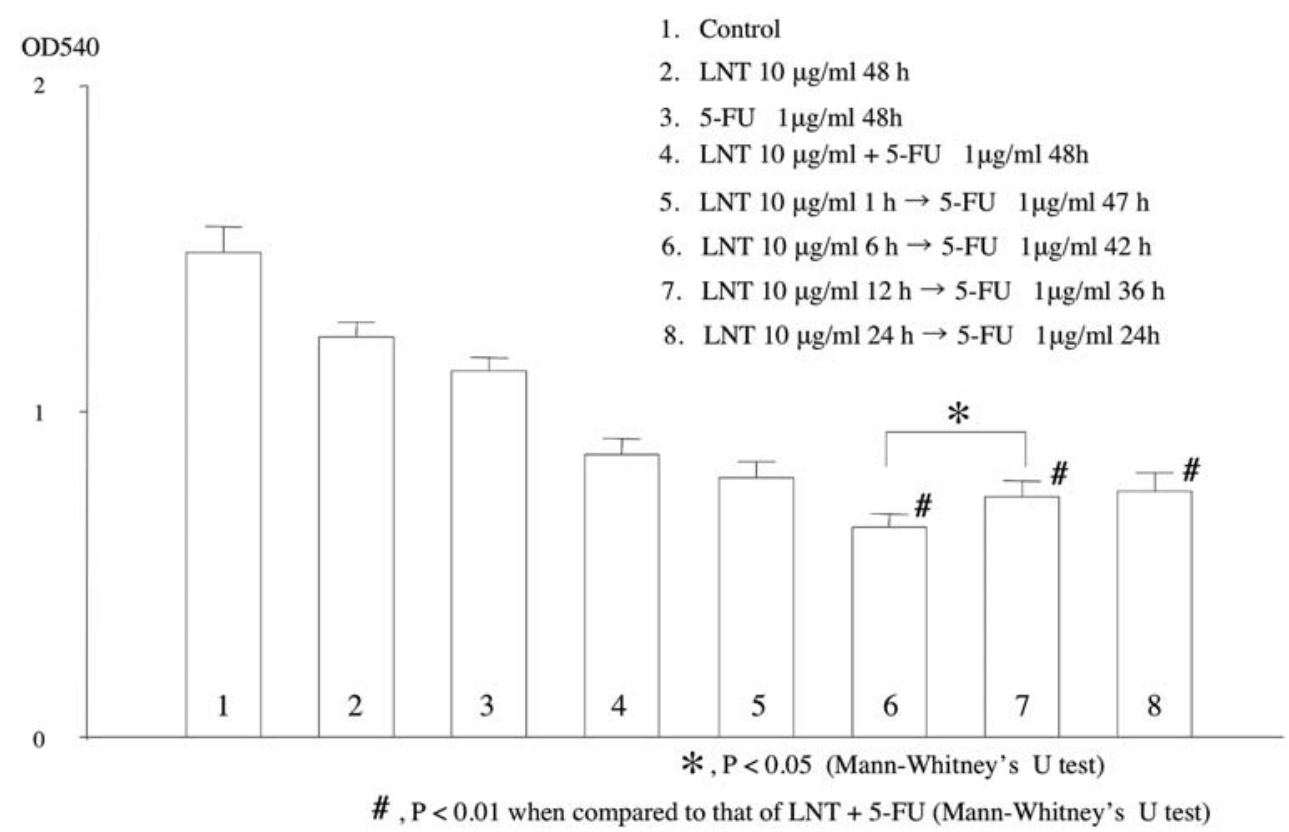

Figure 4. Growth inhibitory effect of LNT in combination with 5 -FU on KB cells. Cells $\left(5 \times 10^{3}\right.$ cells/well) were seeded into 96 -well plates and exposed to LNT and/or 5-FU at the indicated concentration in 10\% FBS-supplemented medium. At different time intervals, cells were counted using a microplate reader. Treatment of LNT $(10 \mu \mathrm{g} / \mathrm{ml})$ for $6 \mathrm{~h}$ before 5 -FU $(1 \mu \mathrm{g} / \mathrm{ml})$ for $42 \mathrm{~h}$ was most effective than treatment of LNT (10 $\mu \mathrm{g} / \mathrm{ml})$ for 1,12 or $24 \mathrm{~h}$ before 5 -FU $(1 \mu \mathrm{g} / \mathrm{ml})$ for 47,36 or $24 \mathrm{~h}$. Each data point represents the mean of six-independent determinations.

$(10 \mu \mathrm{g} / \mathrm{ml})$ for 1,12 or $24 \mathrm{~h}$ before $5-\mathrm{FU}(1 \mu \mathrm{g} / \mathrm{ml})$ for 47,36 or $24 \mathrm{~h}$, respectively (Fig. 4).
Cell cycle analysis. Cell cycle changes associated with the combined treatment of LNT and 5-FU in KB cells were 


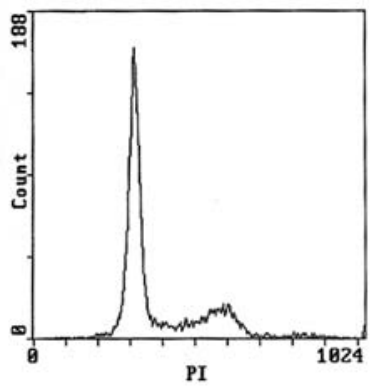

D-MEM $6 \mathrm{~h} \Rightarrow$ D-MEM $42 \mathrm{~h}$

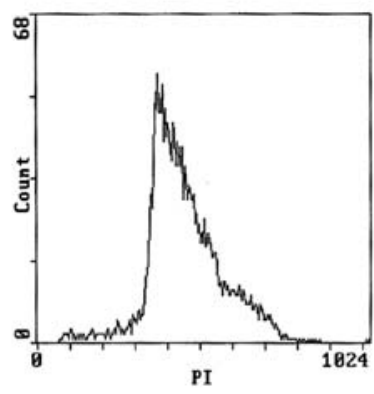

D-MEM $6 \mathrm{~h} \Rightarrow 5$-FU 42h

$(1 \mu \mathrm{g} / \mathrm{ml})$

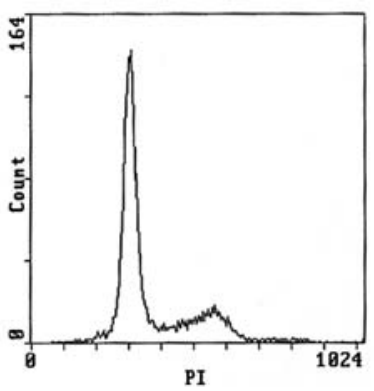

LNT $6 \mathrm{~h} \Rightarrow \mathrm{D}-\mathrm{MEM} 42 \mathrm{~h}$ $(10 \mu \mathrm{g} / \mathrm{ml})$

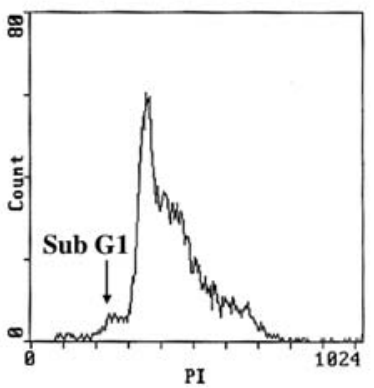

LNT $6 \mathrm{~h} \Rightarrow 5$-FU 42h $(10 \mu \mathrm{g} / \mathrm{ml})(1 \mu \mathrm{g} / \mathrm{ml})$
Figure 5. Analysis of apoptosis by flow cytometry. KB cells were cultured and exposed to LNT and/or 5-FU at the indicated concentration in $10 \%$ FBS-supplemented medium. After cells were staining with $40 \mu \mathrm{g} / \mathrm{ml}$ propidium iodine at different time intervals, the cell cycle was analysed by a digital flow cytometry system. The sub-G1 peak was detected in the treatment of LNT $(10 \mu \mathrm{g} / \mathrm{ml})$ for $6 \mathrm{~h}$ before 5 -FU $(1 \mu \mathrm{g} / \mathrm{ml})$ for $42 \mathrm{~h}$ though the sub-G1 peak was no seen in the treatment of D-MEM for $6 \mathrm{~h}$ before 5-FU $(1 \mu \mathrm{g} / \mathrm{ml})$ for $42 \mathrm{~h}$. Arrows indicate sub-G1 peak.

analysed using flow cytometry. A cell cycle change was not detected between the treatment of D-MEM for $6 \mathrm{~h}$ before D-MEM for $42 \mathrm{~h}$ and the treatment of LNT $(10 \mu \mathrm{g} / \mathrm{ml})$ for $6 \mathrm{~h}$ before D-MEM for $42 \mathrm{~h}$. We detected a sub-G1 peak in the treatment of LNT $(10 \mu \mathrm{g} / \mathrm{ml})$ for $6 \mathrm{~h}$ before 5 -FU $(1 \mu \mathrm{g} / \mathrm{ml})$ for $42 \mathrm{~h}$ though the sub-G1 peak was no seen in the treatment of D-MEM for $6 \mathrm{~h}$ before 5-FU (1 $\mu \mathrm{g} / \mathrm{ml})$ for $42 \mathrm{~h}$ (Fig. 5).

Reduction of TS and DPD protein, and induction of OPRT protein by $L N T$. Western blot analyses demonstrated that the expression of TS and DPD protein by LNT was decreased in a time-dependent manner within the $72 \mathrm{~h}$ period of examination in KB cells. On the other hand, expression of OPRT protein was increased by LNT in a time-dependent manner within $72 \mathrm{~h}$ examined. However, the expression of TS, DPD and OPRT protein was not changed markedly in untreated KB cells. The expression of $\alpha$-tubulin was used as an internal control (Fig. 6).

ELISA also demonstrated that the expression of TS and DPD protein by LNT was decreased in a dose-dependent manner at $24 \mathrm{~h}$ treatment in $\mathrm{KB}$ cells. On the other hand, expression of OPRT was increased by LNT in a dosedependent manner at $24 \mathrm{~h}$ treatment in KB (Table I).

Antitumor effects of LNT alone and in combination with $S-1$ on tumor growth. Mice were treated with $0.1 \mathrm{mg} / \mathrm{kg}$ doses of

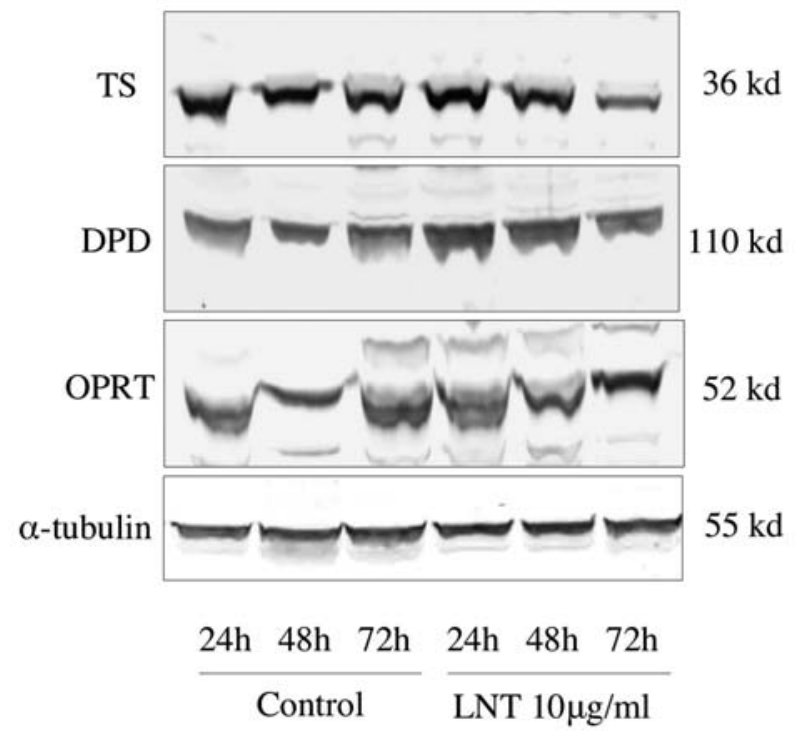

Figure 6. Expression of TS, DPD and OPRT protein in LNT-treated cells. $\mathrm{KB}$ cells were treated with 0 or $10 \mathrm{mg} / \mathrm{ml} \mathrm{LNT}$ for $24-72 \mathrm{~h}$, and the cell lysates were obtained for Western blot analysis. Equal amount of cellular protein $(50 \mu \mathrm{g})$ was subjected to SDS-PAGE, followed by Western blot analysis for TS, DPD and OPRT protein. $\alpha$-tubulin was used as a control for equal protein load. The expression of TS and DPD protein by LNT was decreased, and the expression of OPRT was increased by LNT in a timedependent manner within $72 \mathrm{~h}$ examined.

Table I. Protein levels of TS, DPD and OPRT in OSCC cells with the treatments.

\begin{tabular}{llccc}
\hline KB 24 h treatment & TS & DPD & OPRT \\
\hline Control & $0(\mu \mathrm{g} / \mathrm{ml})$ & 403.6 & 82.6 & 5.98 \\
& $0.1(\mu \mathrm{g} / \mathrm{ml})$ & 270.0 & 65.8 & 6.61 \\
LNT & $1.0(\mu \mathrm{g} / \mathrm{ml})$ & 212.4 & 64.1 & 7.67 \\
& $10.0(\mu \mathrm{g} / \mathrm{ml})$ & 192.5 & 54.6 & 8.44 \\
\hline
\end{tabular}

$\mathrm{ng} / \mathrm{mg}$ protein.

LNT (twice/week) alone and in combination with $6.9 \mathrm{mg} / \mathrm{kg}$ S-1 (7 times/week) for 3 weeks, and tumor growth was observed during the treatment period. Growth inhibition was not seen in LNT treated tumors when compared to HPMC treated tumors. However, the growth inhibition was detected in S-1 treated tumors and S-1+LNT treated tumors. In addition, the growth inhibition of $\mathrm{S}-1+\mathrm{LNT}$ treated tumors was statistically significant when compared to that of S-1 treated tumors. No loss of body weight was observed in mice treated with LNT and/or S-1 during the experimental period in $\mathrm{KB}$ tumors (Fig. 7).

Analysis of apoptosis after LNT alone and in combination with $S-1$ on nude mouse tumors. To analyze the degree of apoptosis, tumors were removed from mice after treatment and the number of apoptotic cells was quantified by the TUNEL assay. The degree of apoptosis in the tumors treated 


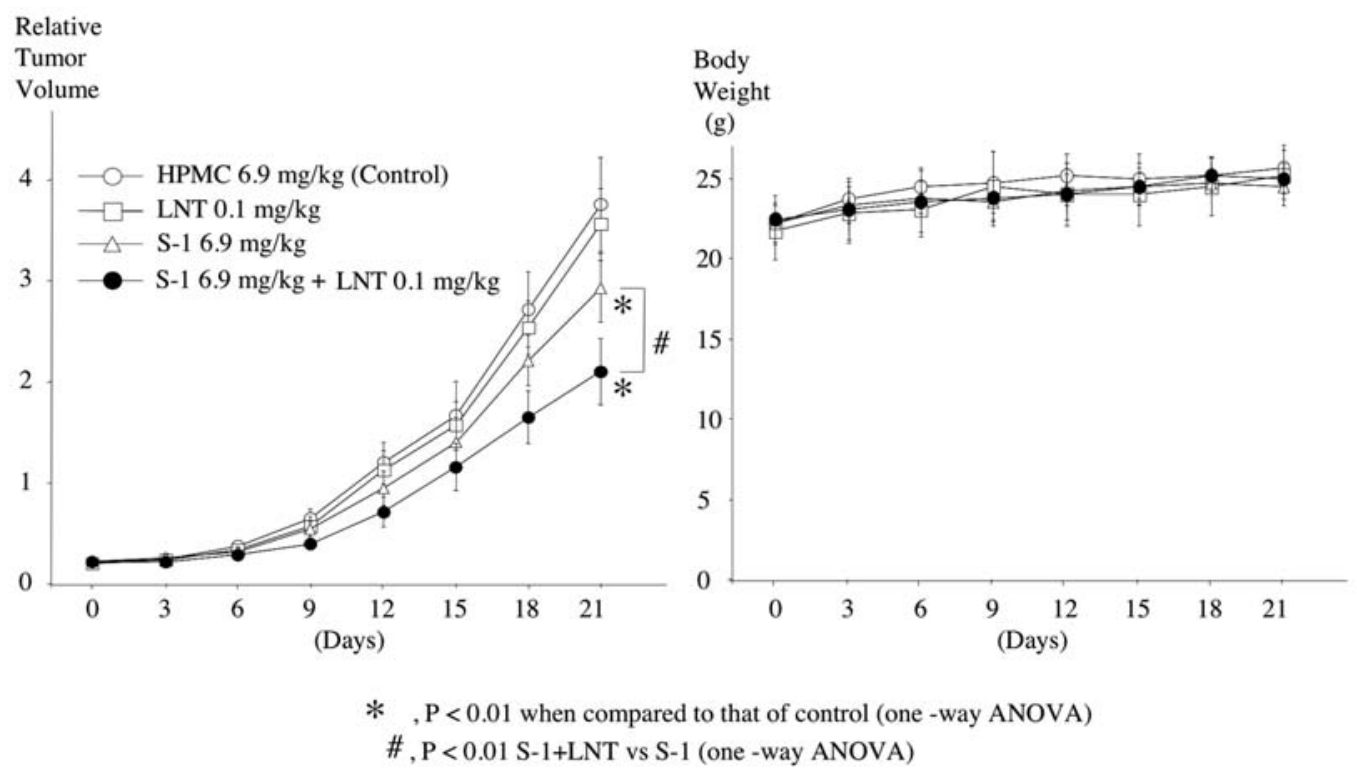

Figure 7. Effect of LNT alone, S-1 alone, and combination with LNT and S-1 on KB tumor growth and body weight in nude mice. Growth inhibition effects of S-1 alone, or LNT plus S-1 were statistically significant when compared to that of control $\left({ }^{*} \mathrm{P}<0.01\right)$. The combination of LNT and $\mathrm{S}-1$ treatment was more effective than $\mathrm{S}-1$ alone $\left({ }^{\#} \mathrm{P}<0.01\right)$. Each group had 5 mice. The values shown are the mean of five tumors ( $\left.\mathrm{mm}^{3}\right)$. During the experimental period no loss of body weight was observed in mice treated with LNT and/or S-1. Bars, SD.

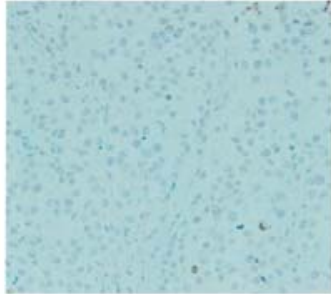

HPMC

TUNEL Positive

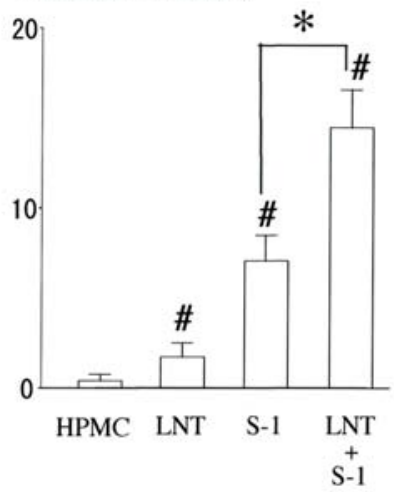

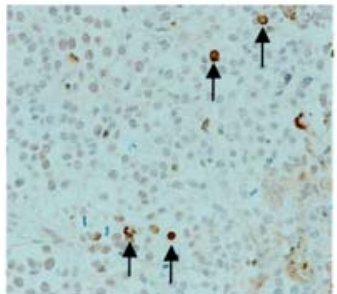

S-1

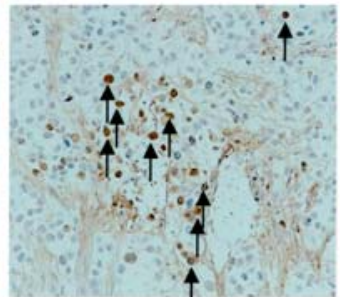

$\mathrm{LNT}+\mathrm{S}-1$

$\uparrow$ Apoptotic cells

$\#, \mathrm{P}<0.05$ when compared to that of HPMC (Mann-Whitney's U test)

$*, \mathrm{P}<0.01$ (Mann-Whitney's U test)

Figure 8. TUNEL assay. The largest number of apoptotic cells was seen in the tumors treated with LNT and/or S-1. Arrows show apoptotic cells (original magnification x300). Analysis of the degree of apoptosis present in tumors treated with LNT alone, S-1 alone and LNT plus S-1. The TUNEL positive cells were significantly increased in LNT alone, S-1 alone and combination with LNT and S-1 treated tumors when compared to that of control ("P<0.05). The LNT and S-1 treatment more markedly induced apoptosis than S-1 alone $\left({ }^{*} \mathrm{P}<0.01\right)$. Bars, SD.

with either LNT or S-1 alone was significantly higher than that seen in the control group. The largest number of apoptotic cells was seen in the tumors treated with the LNT and S-1 combination. This combination treatment significantly induced apoptosis compared to each agent alone as well as the control (Fig. 8). The extent of apoptosis (the number of TUNEL positive cells) in the groups with KB tumors was as follows: Control group, 0.72 \pm 0.34 ; LNT

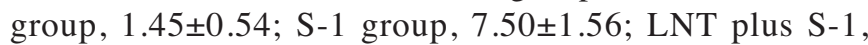
$14.3 \pm 2.11$.

Gene expression levels of TS, DPD and OPRT in nude mouse tumors. KB tumors were also examined for gene expression levels of TS, DPD and OPRT by microdissection and real- 
Table II. Gene expression levels of TS, DPD and OPRT in nude mouse tumors with the treatments.

\begin{tabular}{lccc}
\hline Treatment & TS & DPD & OPRT \\
\hline HPMC & 23.5 & 1.92 & 2.68 \\
LNT $(0.1 \mathrm{mg} / \mathrm{kg})$ & 12.9 & 1.78 & 2.73 \\
S-1 $(6.9 \mathrm{mg} / \mathrm{kg})$ & 18.9 & 1.57 & 3.05 \\
LNT+S-1 & 14.2 & 1.53 & 3.12 \\
& TS/ß-actin & DPD $/ 3$-actin & OPRT/ß-actin \\
\hline
\end{tabular}

Table III. Protein levels of TS, DPD and OPRT in nude mouse tumors with the treatments.

\begin{tabular}{lccc}
\hline Treatment & TS & DPD & OPRT \\
\hline HPMC & 600.6 & 62.3 & 5.26 \\
LNT $(0.1 \mathrm{mg} / \mathrm{kg})$ & 361.8 & 53.5 & 5.41 \\
S-1 $(6.9 \mathrm{mg} / \mathrm{kg})$ & 512.7 & 45.2 & 6.02 \\
LNT+S-1 & 394.5 & 43.1 & 6.39 \\
\hline
\end{tabular}

$\mathrm{ng} / \mathrm{mg}$ protein.

time RT-PCR. TS mRNA expression was reduced in S-1treated tumors and even more reduced in LNT or LNT plus $\mathrm{S}$-1-treated tumors. DPD mRNA expression was reduced in LNT, S-1 and LNT plus S-1-treated tumors. OPRT mRNA expression was increased slightly in S-1, LNT and LNT plus S-1- treated tumors. Briefly, combined treatment of LNT and S-1 also induced down-regulation of TS mRNA and DPD mRNA expression and the up-regulation of OPRT mRNA expression in KB tumors (Table II).

Protein levels of TS, DPD and OPRT in nude mouse tumors. The protein levels of TS, DPD and OPRT in KB tumors were measured by ELISA. The TS protein level was lower in S-1treated tumors and even more reduced in LNT or LNT plus S-1-treated tumors. The DPD protein level was lower in LNT, S-1 and LNT plus S-1-treated tumors. The OPRT protein level was slightly higher in S-1, LNT and LNT plus S-1treated tumors. Briefly, the combined treatment of LNT and S-1 induced the down-regulation of TS protein and DPD protein and the up-regulation of OPRT protein level in KB tumors similarly to each gene expression (Table III).

\section{Discussion}

Although many anticancer agents, such as fluoropyrimidine agents, platinum agents, taxanes, have been introduced into the therapy for patients with advanced OSCC, their efficacies are still limited and may cause serious side effects or oral dysfunctions. Therefore, there is a general agreement for the need of identification of new therapeutic targets and development of new agents with high efficacy and tolerability. Recently, a wide variety of factors involved in the prediction of chemotherapy with 5-FU against gastrointestinal carcinoma including OSCC were identified (13). The degree of TS, DPD or OPRT protein expression is thought to be one of the most reliable factors. Many studies have reported that various carcinomas with higher expression of TS, DPD and lower expression of OPRT may resist 5-FU-based chemotherapy (14-16). These reports have led to the investigation of a new therapeutic agent that can down-regulate TS and DPD expression and up-regulate OPRT expression against OSCC cells.

In this regard, we paid attention to LNT as a candidate agent. LNT has been reported to exert direct antitumor effects $(5,18)$ as well as various immunomodulatory effects $(4,18-23)$. It is thought that LNT have a lower incidence of side effect. Moreover, LNT in combination of tegafur is only approved for enhancing a survival benefit against unresectable or recurrence gastric cancer in Japan (29). We thought LNT might be a useful agent on safety and efficacy in combination with fluoropyrimidine agents such as S-1, and LNT might down-regulate TS and DPD expression and up-regulate OPRT expression against OSCC cells. As we showed above, LNT alone did not significantly inhibit the growth of KB tumors when compared to that of control. However, the antitumor activity of LNT was greatly augmented by its use in combination with S-1. The mechanism of augmentation of the antitumor activity by combined therapy may also be related to induction of apoptosis (Fig. 8). Combined therapy of LNT and S-1 as well as LNT alone was able to induce the down-regulation of TS and DPD expression and the upregulation of OPRT expression both at the protein and mRNA level. Moreover, LNT alone induced down-regulation of TS expression to a greater extent than combined therapy with LNT and S-1 (Tables II and III). These findings suggested that combined therapy with LNT and S-1 as well as with LNT alone may lead to the enhancement of chemosensitivity to $\mathrm{S}-1$ in OSCC xenograft tumors.

In vitro data demonstrated that LNT induced the downregulation of TS and DPD expression and the up-regulation of OPRT expression both at the protein and mRNA level (Fig. 6 and Table I). In addition, pretreatment of LNT before 5-FU exerted remarkable growth inhibitory effects (Figs. 3 and 4). These findings suggest that LNT may lead to the enhancement of chemosensitivity to 5-FU in OSCC cells.

LNT decreased TS expression level markedly compared to DPD expression level. The combined therapy of LNT and S-1 may be able to exert antitumor effects by downregulating TS and DPD. Combined therapy with LNT and S-1 may exert beneficial antitumor effects on these patients with advanced OSCC resistant to S-1. In this respect, combined therapy with LNT and S-1 may have wide clinical applications.

\section{Acknowledgements}

This study was supported in part by a Grant-in-Aid from the Japanese Ministry of Education, Science and Culture. 


\section{References}

1. Parkin DM, Bray F, Ferlay J and Pisani P: Global cancer statistics, 2002. CA Cancer J Clin 55: 74-108, 2005.

2. Shirasaka T, Shimamoto Y, Ohshimo H, Yamaguchi M, Kato T, Yonekura K and Fukushima M: Development of a novel form of 5-fluorouracil derivative (S-1) directed to the potentiation of the tumor-selective cytotoxicity of 5-fluorouracil by two biochemical modulators. Anticancer Drugs 7: 548-557, 1996.

3. Tatsumi K, Fukushima M, Shirasaka T and Fujii S: Inhibitory effects of pyrimidine, barbituric acid and pyridine derivatives on 5-fluorouracil degradation in rat liver extract. Jpn J Cancer Res 78: 748-755, 1987.

4. Shirasaka T, Shimamoto Y and Fukushima M: Inhibition of oxonic acid on gastrointestinal toxicity of 5-fluorouracil without loss of its antitumor activity in rats. Cancer Res 53: 4004-4009, 1993.

5. Shirasaka T, Nakano K, Takechi T, Satake H, Uchida J, Fujioka A, Nakano K, Ohshimo H, Takeda S and Shirasaka T: Antitumor effect of $1 \mathrm{M}$ tegafur-0.4 M 5-chloro-2,4-dihydroxypyridine-1 $\mathrm{M}$ potassium oxonate (S-1) against human colon carcinoma orthotopically implanted into nude rats. Cancer Res 56: 2602-2606, 1996.

6. Sakata Y, Ohtsu A, Horikoshi N, Sugimachi K, Mitachi Y and Taguchi T: Late Phase II study of novel oral fluoropyrimidine anticancer drug S-1 (1 M tegafur- $0.4 \mathrm{M}$ gimestat- $1 \mathrm{M}$ otastat potassium) in advanced gastric cancer patients. Eur J Cancer 34: 1715-1720, 1998.

7. Ohtsu A, Baba H, Sakata Y, Mitachi Y, Horikoshi N, Sugimachi K and Taguchi T: Phase II study of S-1, a novel oral fluoropyrimidine derivative, in patients with metastatic colorectal carcinoma. Br J Cancer 83: 141-145, 2000.

8. Kawahara M, Furuse K, Segawa Y, Yoshimori K, Matsui K, Kudoh S, Hasegawa K and Niitani H: S-1 Cooperative Study Group (Lung Cancer Working Group), Phase II study of S-1, a novel oral fluorouracil, in advanced non-small cell lung cancer. Br J Cancer 85: 939-943, 2001.

9. Inuyama Y, Kida A, Tsukuda M, Kohno N and Satake B: Late phase II study of S-1 in patients with advanced head and neck cancer. Gan To Kagaku Ryoho 28: 1381-1390, 2001.

10. Harada K, Sato M, Ueyama Y, Nagayama M, Hamakawa H, Nagahata S, Yoshimura Y, Osaki T and Ryoke K; Oral Cancer Study Group of Chugoku-Shikoku: Multi-institutional phase II trial of S-1 in patients with oral squamous cell carcinoma. Anticancer Drugs 19: 85-90, 2008.

11. Chollet P, Schoffski P, Weigang-Kohler K, Schellens JH, Cure H, Pavlidis N, Grunwald V, De Boer R, Wanders J and Fumoleau P; EORTC Early Clinical Studies Group: Phase II trial with S-1 in chemotherapy-naive patients with gastric cancer. A trial performed by the EORTC Early Clinical Studies Group (ECSG). Eur J Cancer 39: 1264-1270, 2003.

12. Van den Brande J, Schoffski P, Schellens JH, Roth AD, Duffaud F, Weigang-Kohler K, Reinke F, Wanders J, De Boer RF, Vermorken JB and Fumoleau P; EORTC Early Clinical Studies Group: early phase II trial of S-1 in patients with advanced or metastatic colorectal cancer. Br J Cancer 88: 648-653, 2003.

13. Park JS, Young Yoon S, Kim JM, Yeom YI, Kim YS and Kim NS: Identification of novel genes associated with the response to 5-FU treatment in gastric cancer cell lines using a cDNA microarray. Cancer Lett 214: 19-33, 1991.

14. Kamoshida S, Shiogama K, Shimomura R, Inada K, Sakurai Y, Ochiai M, Matuoka H, Maeda K and Tsutsumi Y: Immunohistochemical demonstration of fluoropyrimidine-metabolizing enzymes in various types of cancer. Oncol Rep 14: 1223-1230, 2005.
15. Miyoshi Y, Uemura H, Ishiguro H, Kitamura H, Nomura N, Danenberg PV and Kubota Y: Expression of thymidylate synthase, dihydropyrimidine dehydrogenase, thymidine phosphorylase and orotate phosphoribosyl transferase in prostate cancer. Prostate Cancer Prostatic Dis 8: 260-265, 2005.

16. Salonga D, Danenberg KD, Johnson M, Metzger R, Groshen S, Tsao-Wei DD, Lenz HJ, Leichman CG, Leichman L, Diasio RB and Danenberg PV: Colorectal tumors responding to 5-fluorouracil have low gene expression levels of dihydropyrimidine dehydrogenase, thymidylate synthase and thymidine phosphorylase. Clin Cancer Res 6: 1322-1327, 2000.

17. Fukushima M, Shimamoto Y, Kato T, et al: Anticancer activity and toxicity of S-1, an oral combination of tegafur and two biochemical modulators, compared with continuous i.v. infusion of 5-fluorouracil. Anticancer Drugs 9: 817-823, 1998.

18. Fukushima M, Satake H, Uchida J, et al: Preclinical antitumor efficacy of S-1: a new oral formulation of 5-fluorouracil on human tumor xenografts. Int J Oncol 13: 693-698, 1998.

19. Nukatsuka M, Fujioka A, Nakagawa F and Fukushima M: Antimetastatic and antitumor effects of fluoropyrimidines alone and combined with Taxanes in a murine model of breast cancer metastatic to the lung. Jpn J Cancer Chemother 29: 95-101, 2002.

20. Cailleau R, Olive M and Cruciger Q: Long-term human breast carcinoma cell lines of metastatic origin: preliminary characterization. In Vitro 14: 911-915, 1978.

21. Spears CP, Shahinian AH, Moran RG, Heidelberg C and Corbett TH: In vivo kinetics of thymidylate synthase inhibition in 5-fluorouracil-sensitive and resistant murine colon adenocarcinomas. Cancer Res 42: 450-456, 1982.

22. Mansour EG, Gray R, Shatila AH, et al: Survival advantage of adjuvant chemotherapy in high-risk node-negative breast cancer: ten-year analysis - an intergroup study. J Clin Oncol 16: 3486$3492,1998$.

23. Naguib FNM, El-Kouni MH and Cha S: Enzymes of uracil catabolism in normal and neoplastic human tissues. Cancer Res 45: 5405-5412, 1985.

24. Carmichael J, De Graff WG, Gazdar AF, Minna JD and Mitchell JB: Evaluation of a tetrazolium-based semiautomated calorimetric assay: assessment of chemosensitivity testing. Cancer Res 47: 936-942, 1987.

25. Chomczynski P and Sacchi N: Single-step method of RNA isolation by acid guanidinium thiocyanate-phenol-chloroform extraction. Anal Biochem 162: 156-159, 1987.

26. Mori K, Hasegawa M, Nishida M, Toma H, Fukuda M, Kubota T, Nagasue N, Yamana H, Hirakawa-YS Chung K, Ikeda T, Takasaki K, Oka M, Kameyama M, Toi M, Fujii H, Kitamura M, Murai M, Sasaki H, Ozono S, Makuuchi H, Shimada Y, Onishi Y, Aoyagi S, Mizutani K, Ogawa M, Nakao A, Kinoshita H, Tono T, Imamoto H, Nakashima $\mathrm{Y}$ and Manabe T: Expression levels of thymidine phosphorylase and dihydropyrimidine dehydrogenase in various human tumor tissues. Int J Oncol 17: 33-38, 2000.

27. Kurebayashi J, Yamamoto Y, Udagawa K, Okubo S, Fukushima $\mathrm{M}$ and Sonoo H: Establishment of enzyme-linked immunosorbent assays for thymidylate synthase and dihydropyriminide dehydrogenase in cancer tissues. Oncol Rep 11: 973-979, 2004.

28. Tsuji T, Sawai T, Takeshita H, Nakagoe T, Hidaka S, Yamaguchi H, Yasutake T, Nagayasu T and Tagawa Y: Tumor dihydropyrimidine dehydrogenase expression is a useful marker in adjuvant therapy with oral fluoropyrimidines after curative resection of colorectal cancer. Cancer Chemother Pharmacol 54: 531-536, 2004.

29. Taguchi T, Furue H, Kimura T, Kondo T, Hattori T, Itoh I and Ogawa N: Results of phase III study of lentinan. Gan To Kagaku Ryoho 12: 366-378, 1985. 